\title{
Macroinvertebrate Communities in a Lake of an Inter-Basin Water Transfer Project and Its Implications for Sustainable Management
}

\author{
Wanxiang Jiang ${ }^{1,2,3}{ }^{-}$, Baozhu Pan ${ }^{1, *}$, Jing Chen ${ }^{2}$, Xiaoming Jiang ${ }^{1, *}$, Henglun Shen ${ }^{2}$ and \\ Tianshun $\mathrm{Zhu}^{2}$ \\ 1 State Key Laboratory of Eco-Hydraulics in Northwest Arid Region of China, Xi'an University of Technology, \\ Xi'an 710048, China; uzzjiang@163.com \\ 2 College of Life Sciences, Zaozhuang University, Zaozhuang 277160, China; chj218.2000@163.com (J.C.); \\ shenhenglun@126.com (H.S.); TianshunZhuEco@163.com (T.Z.) \\ 3 Hebei Key Laboratory of Wetland Ecology and Conservation, Hengshui 053000, China \\ * Correspondence: zhuzipan@xaut.edu.cn (B.P.); jiangxm@xaut.edu.cn (X.J.)
}

Received: 15 June 2020; Accepted: 1 July 2020; Published: 3 July 2020

\begin{abstract}
In the present study, we choose the Weishan Lake, one of important water transfer and storage lakes on the eastern route of the South-to-North Water Diversion Project (SNWD) in China, to clarify how the community structure and assemblage-environment relationships of macroinvertebrates varied across three typical habitats (the River Mouth, Canal and Lake regions) over the four seasons in 2012. A total of 72 taxa belonging to 3 phyla, 9 classes and 24 families were recorded, with tolerant oligochaetes and chironomids as the dominant taxa. The environmental conditions and macroinvertebrate assemblages were clearly separated at spatial and temporal scales. Assemblage structure showed both significant but larger spatial than seasonal variations, with a clear separation of sites from three regions in an ordination plot. Compared to the temporal scale, more indicator species were retained to be responsible for the regional differences according to the two-way cluster analysis. Different environmental variables were significant for distinguishing macroinvertebrate assemblages among four seasons, and among them, $\mathrm{pH}$ was the only variable which was retained in all models. Our study provided useful background information of environmental characteristics and macroinvertebrate communities in a typical water transfer and storage lake before the water transfer of the SNWD. After the operation of SNWD, we envisage inter-basin water transfer (IBWT), which is usually accompanied by water level rise, nutrient pattern change and biota succession, will seriously affect recipient basins. Therefore, we propose several management strategies for SNWD: (1) target and detailed data should be collected on a timely basis; (2) government should prevent water pollution and adopt effective measures to protect the water environment; (3) the environmental assessments and other aspects of IBWT planning should be coordinated; (4) an overall consideration of different basins should be given to achieve a greater range of water resources planning, scheduling, and allocation; and (5) the migration and invasion of species should be of concern during the operation of the project.
\end{abstract}

Keywords: Nansi Lake; Weishan Lake; South-to-North Water Diversion Project; spatiotemporal pattern

\section{Introduction}

Inter-basin water transfer (IBWT) projects have been developed in many countries throughout the world during the past century, due to the contradiction between the limited quantity of water availability and continually growing water demand [1,2]. The IBWT projects have brought enormous economic benefits for human society, however, in the meantime, these projects also draw increasing criticisms because of the associated eco-environmental problems e.g., alterations of hydro-chemical and 
biological parameters patterns [3,4]. China's South-to-North Water Diversion Project (SNWD) is the largest and most expensive inter-basin diversion megaproject in the world. This project commenced in 2002, to balance the nation's water supply by drawing water from southern rivers to the dry north [5]. It has potentially solved the water resource shortage of North China.

The SNWD can effectively improve the ecological environment of lakes, e.g., the water resource crisis of Nansi Lake and Dongping Lakes was effectively alleviated by water diversion in 2016. However, beyond all doubts, a lot of environmental, ecological and even social problems came after the water transfer projects [6]. Therefore, there is an urgent need to study and monitor the effects of water transfer projects with the aim of protecting aquatic ecosystems in a sustainable manner $[7,8]$.

Physical and chemical measurements were traditionally used for monitoring the environmental quality of aquatic ecosystems. However, they do not measure the impact of contaminants on biota $[9,10]$. Furthermore, owing to technical and financial limitations, it is hardly conceivable to determine all possible pollutants occurring in sediment and to measure their concentrations [11]. Biological methods appear as an alternative to chemical detection using living organisms and have the advantage of being simple and easy to implement [8]. For the above reasons, it is necessary to carry out aquatic bio-monitoring for the lakes involved in water diversion projects. Weishan Lake, which is located on the eastern route of SNWD, is an important water transfer and storage lake. Similar to other lakes on the route, despite its role and importance as mentioned above, there are only a few studies on aquatic biota in the lake, especially before the completion and operation of the project. Hence, the relevant research before the project operation is particularly valuable for studying the impact of water transfer on the freshwater ecosystem and developing sustainable management strategies.

Macroinvertebrates are key components in the functioning of a fresh water ecosystem, and also play a significant role in the food chain [12]. In addition, aquatic macroinvertebrates have a wide range of environmental preferences and represent a diverse group that integrates environmental changes over time, and are widely used as bio-indicators in evaluating the impact of human activities on aquatic ecosystem, for instance, land use [13,14], climate [13,15], and nutrient enrichment [16,17]. Moreover, they are frequently used in biodiversity studies because of their high taxonomic heterogeneity [18]. Nevertheless, changes in the macroinvertebrate community composition caused by IBWT projects have rarely been studied. As such, monitoring and early prediction of macroinvertebrate community composition is particularly important, especially in the receiving water system of an IBWT project. So far, there have been only a few reports about macroinvertebrates in the Weishan Lake, especially before the project operated in October 2013.

Spatial and temporal researches on macroinvertebrate communities are the basis of further studies, and have been investigated by many researchers [19-22]. Although assessment methods based on macroinvertebrate are becoming more and more popular in China, the lack knowledge of the environmental and biological data in many regions hinders the development of bio-assessment [23]. Revealing the relationship between macroinvertebrates and environmental factors could describe spatio-temporal changes more accurately [22,24]. In this study, prior to the operation of the water diversion project, we expected to examine the relationships between macroinvertebrate communities and environmental factors, and to propose realizable management strategies for SNWD based on above results for the first time. The main objectives were: (1) to investigate species composition, biodiversity and community characteristics among three regions (River Mouth, Canal and Lake regions) and four seasons (spring, summer, autumn and winter), and identify the indicators; (2) to screen out the key environment factors which play a decisive role in the spatiotemporal distribution of benthic communities; (3) to propose potential management strategies after operation of the SNWD. We expect to lay a good foundation for evaluating the influence of the IBWT project on aquatic ecosystem in the Weishan Lake. 


\section{Materials and Methods}

\subsection{Study Area and Sites Selection}

The eastern and middle routes of the SNWD in China have already been built in October 2013 and December 2014 respectively; these currently deliver 25 billion $\mathrm{m}^{3}$ of freshwater per year [5,25]. The Nansi Lake, locating on the eastern route of the SNWD and covering a surface area of $1266 \mathrm{~km}^{2}$, is the largest lake in Shandong province and the sixth largest freshwater lake in China. It is the most important water delivery channel and storage lake of the country's SNWD, with a total drainage area of $31,700 \mathrm{~km}^{2}$. From north to south, Nansi Lake is connected together by four sublakes: Nanyang Lake, Dushan Lake, Zhaoyang Lake and Weishan Lake [26]. The Second-Dam hydro-project which is located in the middle of the Zhaoyang Lake divided the Nansi Lake into the Upper Lake (north part) and the Lower Lake (south part). The area of the Upper Lake is $606 \mathrm{~km}^{2}$ and the Lower Lake is $660 \mathrm{~km}^{2}$ [27].

The water transfer and storage function of the Nansi Lake is mainly accomplished by the Lower Lake, i.e., the Weishan Lake, which is located at the southern part of Nansi Lake and accounts for the vast majority of the Lower Lake. Weishan Lake has an average depth of $1.5 \mathrm{~m}$ and belongs to a warm temperate and semi-humid monsoon continental climate, with four distinctive seasons, average annual temperature of $13.7^{\circ} \mathrm{C}$, and an average annual precipitation of $700 \mathrm{~mm}$, of which, the summer rainfall accounts for $60 \% \sim 80 \%$ [28-30]. In this study, a total of 12 sites belonging to 3 typical waters (River Mouth region, Canal region and Lake region) were investigated (Figure 1). Among them, four sites (L1-L4) are located in the Lake region; mainly affected by aquaculture (crab purse seine farming was nearby these sites, especially L3 and L4). Five sites (J1-J5) are located on the route of Beijing-Hangzhou Grand Canal (Canal region), mainly affected by hydrological fluctuations caused by large vessels and flood discharge. Three sites (E1-E3) are located in the Xinxue River mouth (River Mouth region), and a large amount of organic and inorganic materials from the upstream settled in this region.

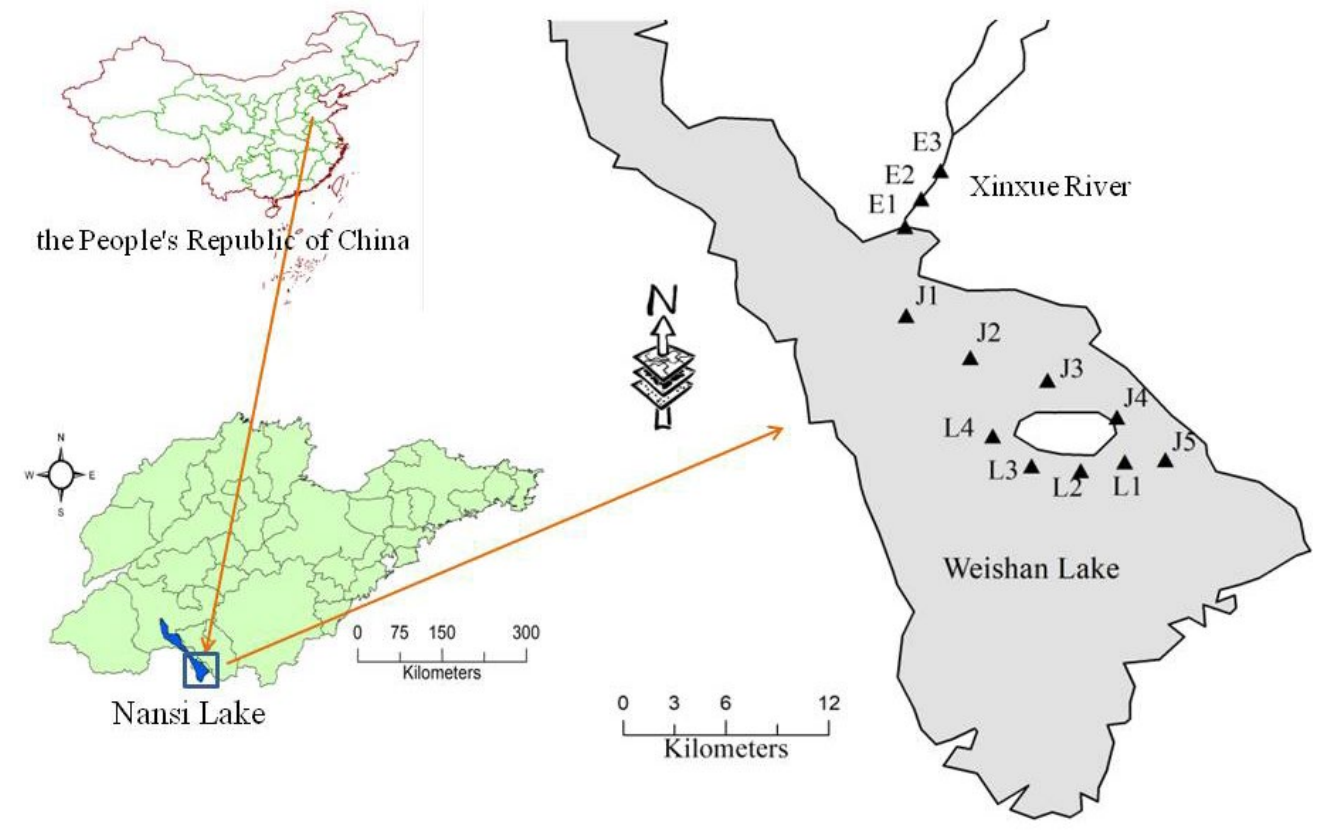

Figure 1. Location of the sampling sites in the Weishan Lake basin.

\subsection{Macroinvertebrate Collection and Identification}

Macroinvertebrates were seasonally collected at the 12 sites in April, July, October and December 2012, respectively. At each site, three replicate quantitative sediment samples for macroinvertebrates were collected with a modified Peterson grab whose opening area was $0.0625 \mathrm{~m}^{2}$. The samples were then sieved with a $0.45-\mathrm{mm}$ sieve in the field. The remaining material was kept individually 
in self-sealing bags and stored in an incubator. In the laboratory, specimens were sorted out from the retained material and preserved in 10\% formalin. Animals were identified to the lowest feasible taxonomic level under a dissection microscope (Olympus ${ }^{\circledR}$ SZ61) and a microscope (Olympus ${ }^{\circledR}$ BX53) according to relevant references [31-36], and counted. Wet weight of each taxon was obtained with an electronic balance (accurate to $0.0001 \mathrm{~g}$ ) after blotted by blotting paper.

\subsection{Environmental Variables}

On each sample occasion, environmental variables were measured prior to macroinvertebrate sampling. Water temperature (WT), $\mathrm{pH}$, dissolved oxygen (DO), electrical conductivity (Cond), total dissolved solids (TDS) were in situ measured (about $0.5 \mathrm{~m}$ below the surface) using a YSI 556 multi-parameter water quality sonde. Sediment temperature (ST), water transparency (SD), and water depth (WD) were also measured by a temperature sensor (SBTWZP), Secchi disc and a rod with gradations, respectively. Water samples were collected to quantify the total amounts of nitrogen (TN), ammonium $\left(\mathrm{NH}_{4}-\mathrm{N}\right)$, nitrate $\left(\mathrm{NO}_{3}-\mathrm{N}\right)$, total phosphorus $(\mathrm{TP})$, orthophosphate $\left(\mathrm{PO}_{4}-\mathrm{P}\right)$ and Chlorophyll a (Chl-a) in the laboratory. All of the water samples were measured according to the environmental quality standards for surface water of China [37] and the standard methods for observation and analysis in China [38].

\subsection{Biodiversity Indices and Date Analysis}

Four diversity indices, including species richness $(R)$, Shannon-Weiner index $(H)$, Margalef index $(M)$, and Pielou's evenness index $(J)$, were calculated by the following equations:

$$
\begin{aligned}
& R=S, \\
& H=-\sum\left(n_{i} / N\right) \ln \left(n_{i} / N\right), \\
& M=(S-1) / \ln N, \\
& \mathrm{~J}=H / \ln S,
\end{aligned}
$$

where $S, n_{i}$ and $N$ are the species number, abundance of species $i$, and total abundance of all species in a site, respectively.

One-way, repeated-measures analysis of variances (ANOVAs) was carried out on the parameters based on macroinvertebrate data (density, biomass, richness, Shannon-Wiener index, Margalef index, evenness index, relative abundance and density of the main groups) to detect the difference among 3 regions and 4 seasons. To group sites with similar macroinvertebrate assemblages, non-metric multidimensional scaling (NMDS) was performed, based on the Bray-Curtis similarity matrix [39]. Permutational analysis of variance (PERMANOVA) was also carried out on the Bray-Curtis similarity matrix to determine the main sources of spatial and temporal variation in the data, with two explanatory variables (region and season) and 9999 permutations [40,41]. Indicator species among seasons and regions were analyzed to identify the taxa responsible for observed differences [39]. Then, to reveal the indicative action of the indicator species, two-way cluster analysis based on them was carried out [39]. Finally, distanced-based redundancy analysis (db-RDA) was explored to examine how environmental variables drive variation in assemble composition among regions and seasons [42]. We used forward selection and Monte Carlo permutations to select the minimum set of environmental variables that were significantly associated with macroinvertebrate distributions. Prior to the above analysis, macroinvertebrate abundance and data were $\log (x+1)$ transformed. Environment variables were checked for normality and $\log (x+1)$ transformed when necessary.

Repeated-measures analysis of variances was carried out in IBMSPSS software (version 19.0); NMDS, indicator species analysis, two-way cluster analysis in PCORD 5, and PERMANOVA, dbRDA in PERMANOVA $^{+}$for PRIMER. 


\section{Results}

\subsection{Physicochemical Parameters}

Most environmental parameters were significantly different among regions and seasons (Tables 1 and A1). In terms of three regions, except for WD, WT and ST, all the rest of the parameters were significantly different among regions (Kruskal-Wallis test, $p<0.05$ ). Among them, SD was lowest in the Canal region (39.1 versus 71.1, $63.6 \mathrm{~cm}$ in River Mouth and Lake regions); nutrients $\left(\mathrm{TN}, \mathrm{NO}_{3}-\mathrm{N}\right.$, $\mathrm{NH}_{4}-\mathrm{N}, \mathrm{TP}, \mathrm{PO}_{4}-\mathrm{P}$ ) and TDS were highest, but Chl-a was lowest in the River Mouth region. The sites in the Lake region had the highest values of $\mathrm{DO}$ and $\mathrm{pH}$ value, but the lowest value of conductivity. With the exception of Chl- $a, \mathrm{TP}, \mathrm{PO}_{4}-\mathrm{P}$, TDS, and Cond, the difference in other parameters were found to be significant among seasons (Kruskal-Wallis test, $p<0.05$ ). WD, SD, DO were lowest, but WT, ST were highest in summer. $\mathrm{TN}, \mathrm{NH}_{4}-\mathrm{N}, \mathrm{NO}_{3}-\mathrm{N}$ were highest in autumn, while $\mathrm{pH}$ was higher in spring and summer. In one word, the vast majority of environmental factors showed strong temporal and spatial variability.

Table 1. Kruskal-Wallis tests were conducted to detect differences of parameters among seasons and regions.

\begin{tabular}{|c|c|c|c|c|c|c|}
\hline \multirow{2}{*}{ Factors } & \multicolumn{3}{|c|}{ Seasons } & \multicolumn{3}{|c|}{ Regions } \\
\hline & $\mathrm{X}^{2}$ & $d f$ & $p$ & $X^{2}$ & $d f$ & $p$ \\
\hline water depth (WD) & 18.99 & 3 & $<0.001$ & 2.07 & 2 & 0.355 \\
\hline water temperature (WT) & 42.11 & 3 & $<0.001$ & 1.73 & 2 & 0.42 \\
\hline sediment temperature (ST) & 44.45 & 3 & $<0.001$ & 0.68 & 2 & 0.712 \\
\hline water transparency (SD) & 22.78 & 3 & $<0.001$ & 12.64 & 2 & 0.002 \\
\hline Chlorophyll a (Chl-a) & 5.24 & 3 & 0.155 & 21.79 & 2 & $<0.001$ \\
\hline total nitrogen $(\mathrm{TN})$ & 21.56 & 3 & $<0.001$ & 19.39 & 2 & $<0.001$ \\
\hline nitrate $\left(\mathrm{NO}_{3}-\mathrm{N}\right)$ & 8.85 & 3 & 0.031 & 25.85 & 2 & $<0.001$ \\
\hline ammonium $\left(\mathrm{NH}_{4}-\mathrm{N}\right)$ & 21.33 & 3 & $<0.001$ & 22.08 & 2 & $<0.001$ \\
\hline total phosphorus (TP) & 4.56 & 3 & 0.207 & 32.93 & 2 & $<0.001$ \\
\hline orthophosphate $\left(\mathrm{PO}_{4}-\mathrm{P}\right)$ & 4.51 & 3 & 0.211 & 37.5 & 2 & $<0.001$ \\
\hline total dissolved solids (TDS) & 4.8 & 3 & 0.187 & 31.97 & 2 & $<0.001$ \\
\hline dissolved oxygen (DO) & 10.85 & 3 & 0.013 & 16.66 & 2 & $<0.001$ \\
\hline electrical conductivity (Cond) & 3.89 & 3 & 0.274 & 23.87 & 2 & $<0.001$ \\
\hline $\mathrm{pH}$ & 21.16 & 3 & $<0.001$ & 20.19 & 2 & $<0.001$ \\
\hline
\end{tabular}

\subsection{Species Composition}

During the investigation period, a total of 72 taxa belonging to 3 phyla (Arthropoda, Mollusca, Annelida), 9 classes and 24 families were recorded in 48 sampling sites among 4 seasons. Among them there were 39 insects, 15 mollusks, 11 oligochaets and 7 miscellaneous animals (Tables 2 and A2). Species with relative abundance greater than $5 \%$ were defined as dominant taxa [43], and Limnodrilus hoffmeisteri, Propsilocerus akamusi, Tanypus concavus, Culicoides sp. were classified as the dominant taxa over the investigation period, with relative abundances were $27.9 \%, 20.9 \%, 15.6 \%$ and $7.1 \%$, respectively.

Dominant species varied greatly among research regions and seasons (Table 2). A total of 9 taxa among different regions ( 5 in the River Mouth region, 4 in the Canal region, 2 in the Lake region) and seasons ( 2 in spring, 4 in summer and autumn, 3 in winter) were identified. Among them, Limnodrilus hoffmeisteri was the only common dominant species in all seasons and regions.

Table 2. Relative abundance (\%) of dominate taxa among different research regions and seasons in Weishan Lake.

\begin{tabular}{|c|c|c|c|c|c|c|c|c|}
\hline Dominate Taxa & Annual & River Mouth & Canal & Lake & Spring & Summer & Autumn & Winter \\
\hline Limnodrilus hoffmeisteri & 27.9 & 20.1 & 43.5 & 33.1 & 53.5 & 27.4 & 31.0 & 28.8 \\
\hline Propsilocerus akamusi & 20.9 & 39.4 & & & 17.8 & & & 5.2 \\
\hline Tanypus concavus & 15.6 & 5.9 & & 39.7 & & 14.9 & 33.8 & 42.1 \\
\hline Microchironomus tener & & 7.7 & & & & 22.6 & & \\
\hline Culicoides sp. & 7.1 & 14.3 & & & & & 6.6 & \\
\hline Limnodilus claparedianus & & & 8.5 & & & 9.8 & & \\
\hline Bellamya purificata & & & 10.7 & & & & & \\
\hline Hemiclepsis sp. & & & 5.5 & & & & & \\
\hline Alocinma longicornis & & & & & & & 6.4 & \\
\hline
\end{tabular}




\subsection{Density, Biomass, Biodiversity Indices and Main Taxa Groups}

Repeated-measure ANOVAs revealed that density, Margalef index, species richness, Shannon-Weiner index and the main taxa groups (density of Chironomidae, relative abundance of Chironomidae, Oligochaeta and Mollusca) were significantly different among regions $(p<0.05)$ (Table 3, Figure 2). The Margalef index, Shannon-Weiner index, and relative abundance of Oligochaeta and Mollusca were highest in the Canal region $(p<0.05)$, while density, species richness, density and relative abundance of Chironomidae were significantly higher in the River Mouth region $(p<0.05)$. Among the four seasons, the maximum values of density, species richness, density and relative abundance of Chironomidae all occurred in winter $(p<0.05)$; relative abundance of Oligochaeta in spring was higher than other seasons $(p<0.05)$ (Table 3, Figure 2$)$. Finally, for region $\times$ season interactions, density, Shannon-Weiner index, density of Chironomidae and Mollusca showed significant difference $(p<0.05)$ (Table 3, Figure 2). In contrast, the influence of between/within-subjects and interactions on biomass, evenness index and Oligochaeta density were not significant $(p>0.05)$ (Table 3, Figure 2).

Table 3. Repeated measured ANOVAs of effects of regions in four seasons on biomass, density, diversity indices (Shannon-Weiner, richness, evenness, Margalef) and the density and relative abundance of main groups (Chironomidae, Oligochaeta, Mollusca). $p$-values $<0.05$ are in bold.

\begin{tabular}{|c|c|c|c|}
\hline & $F$ & $p$-Value & Ranking (Post Hoc Test or Contrasts) \\
\hline \multicolumn{4}{|l|}{ Biomass } \\
\hline Between-subjects (regions) & 3.41 & 0.079 & \\
\hline Within-subjects (seasons) & 1.22 & 0.321 & \\
\hline Season $\times$ region & 2.21 & 0.073 & \\
\hline \multicolumn{4}{|l|}{ Density } \\
\hline Between-subjects (regions) & 55.18 & $<0.001$ & River Mouth $>$ Lake $>$ Canal \\
\hline Within-subjects (seasons) & 14.17 & $<0.001$ & Spring vs. summer vs. autumn vs. winter \\
\hline Season $\times$ region & 5.86 & $<0.001$ & Spring vs. summer vs. autumn vs. winter \\
\hline \multicolumn{4}{|l|}{ Evenness index } \\
\hline Between-subjects (regions) & 2.62 & 0.127 & \\
\hline Within-subjects (seasons) & 0.36 & 0.779 & \\
\hline Season $\times$ region & 1.94 & 0.110 & \\
\hline \multicolumn{4}{|l|}{ Margalef index } \\
\hline Between-subjects (regions) & 10.04 & 0.005 & Canal > Lake \\
\hline Within-subjects (seasons) & 2.28 & 0.102 & \\
\hline season $\times$ region & 1.20 & 0.335 & \\
\hline \multicolumn{4}{|l|}{ Species richness } \\
\hline Between-subjects (regions) & 8.16 & 0.010 & River Mouth, Canal > Lake \\
\hline Within-subjects (seasons) & 2.84 & 0.057 & Autumn vs. winter $(F=13.48, p=0.005)$ \\
\hline Season $\times$ region & 1.08 & 0.402 & \\
\hline \multicolumn{4}{|l|}{ Shannon-Weiner index } \\
\hline Between-subjects (regions) & 4.67 & 0.041 & Canal > Lake \\
\hline Within-subjects (seasons) & 1.63 & 0.206 & \\
\hline Season $\times$ region & 2.50 & 0.047 & Spring vs. all others \\
\hline \multicolumn{4}{|l|}{ Density of Chironomidae } \\
\hline Between-subjects (regions) & 41.04 & $<0.001$ & River Mouth $>$ Lake $>$ Canal \\
\hline Within-subjects (seasons) & 19.81 & $<0.001$ & Spring vs. summer vs. autumn vs. winter \\
\hline Season $\times$ region & 11.10 & 0.015 & Spring vs. all others, autumn vs. winter \\
\hline \multicolumn{4}{|l|}{$\%$ Chironomidae } \\
\hline Between-subjects (regions) & 101.99 & $<0.001$ & River Mouth, Lake $>$ Canal \\
\hline Within-subjects (seasons) & 3.85 & 0.021 & Spring vs. all others, autumn vs. winter \\
\hline Season $\times$ region & 3.62 & 0.009 & \\
\hline \multicolumn{4}{|l|}{ Density of Oligochaeta } \\
\hline Between-subjects (regions) & 2.17 & 0.171 & \\
\hline Within-subjects (seasons) & 0.46 & 0.716 & \\
\hline Season $\times$ region & 1.30 & 0.291 & \\
\hline \multicolumn{4}{|l|}{$\%$ Oligochaeta } \\
\hline Between-subjects (regions) & 6.41 & 0.019 & Canal > River Mouth \\
\hline Within-subjects (seasons) & 2.47 & 0.084 & Spring vs. all others \\
\hline Season $\times$ region & 1.11 & 0.382 & \\
\hline \multicolumn{4}{|l|}{ Density of Mollusca } \\
\hline Between-subjects (regions) & 1.49 & 0.277 & \\
\hline Within-subjects (seasons) & 1.86 & 0.161 & \\
\hline Season $\times$ region & 3.55 & 0.073 & \\
\hline \multicolumn{4}{|l|}{$\%$ Mollusca } \\
\hline Between-subjects (regions) & 6.14 & 0.021 & Canal > River Mouth, Lake \\
\hline Within-subjects (seasons) & 0.17 & 0.916 & \\
\hline Season $\times$ region & 1.20 & 0.339 & \\
\hline
\end{tabular}



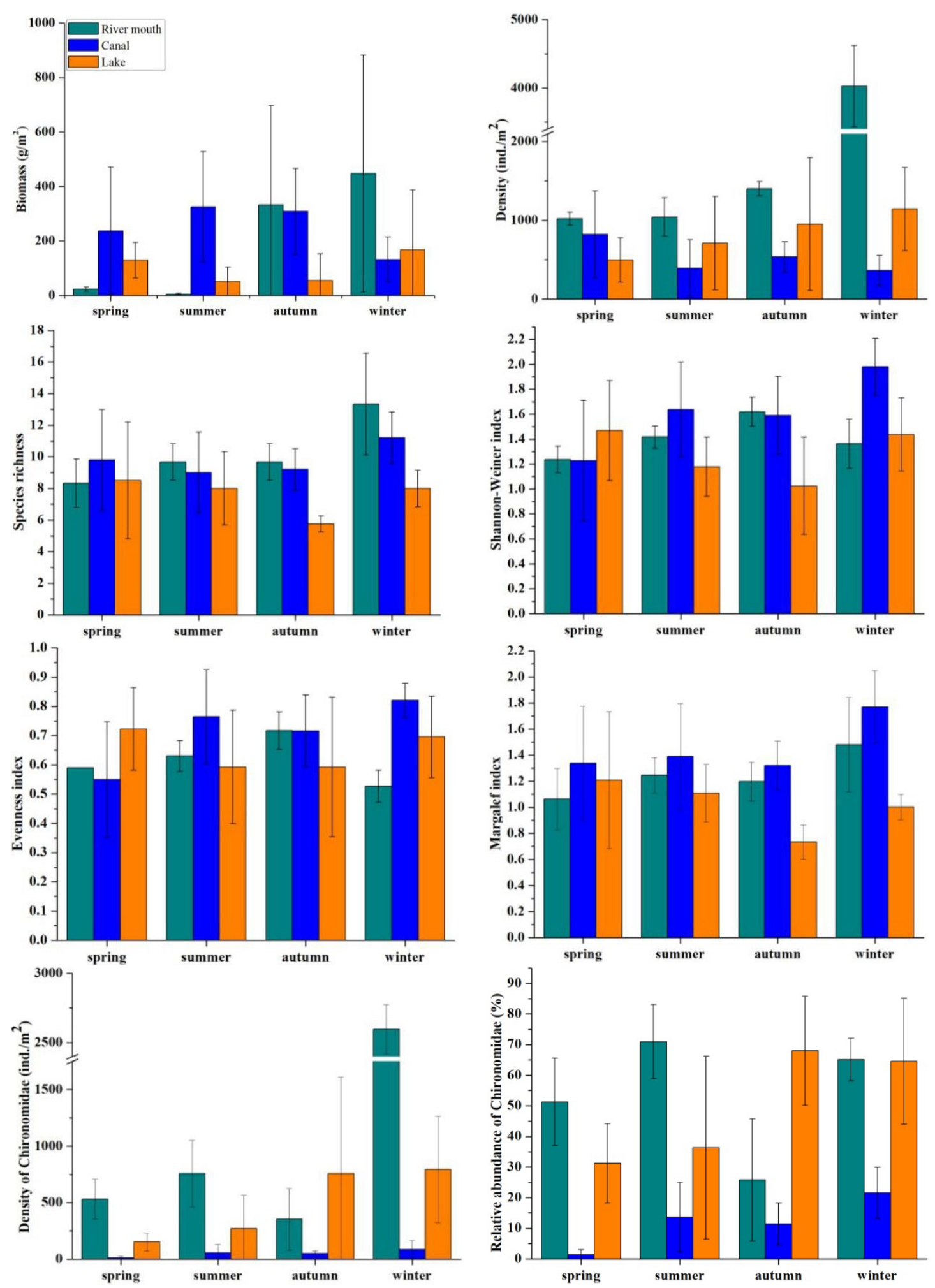

Figure 2. Cont. 

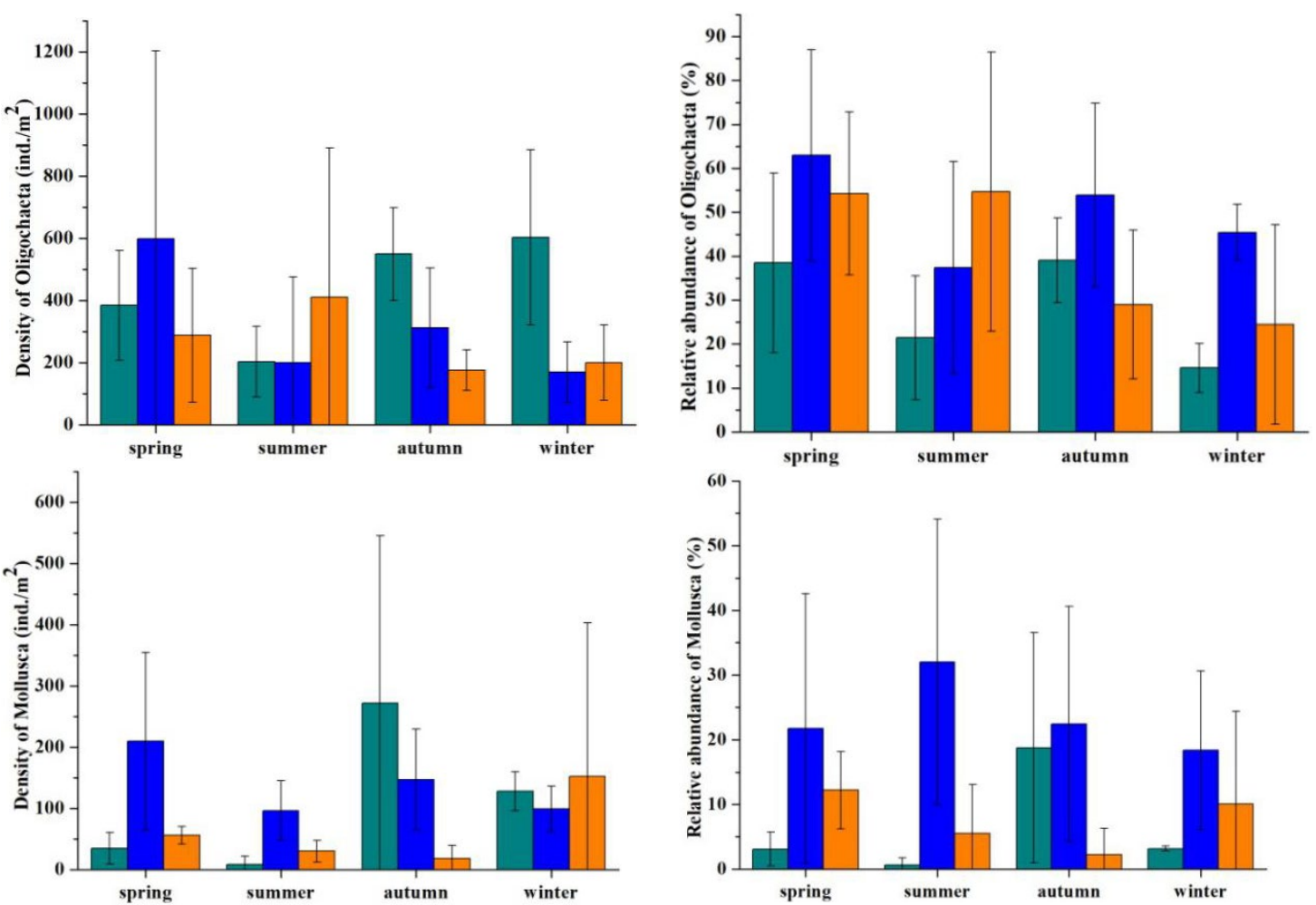

Figure 2. Spatial and temporal variations of macroinvertebrate biomass, density, biodiversity indices, and main taxa groups (density and relative abundance of Chironomidae, Oligochaeta and Mollusca).

\subsection{Community Structure}

NMDS ordinations showed the separation of macroinvertebrate communities among regions was clearer than seasons (Figure 3). PERMANOVA indicated that the source of variation in macroinvertebrate assemblages among regions, seasons and region $\times$ season were all significant $(p<0.05)$ (Table 4). Pair-wise tests of PERMANOVA analysis indicated that the primary source of variation in macroinvertebrate assemblages was mainly due to spatial heterogeneity of the research area, and the spring samples being quite different to other seasons in Canal and Lake regions (Table A3).
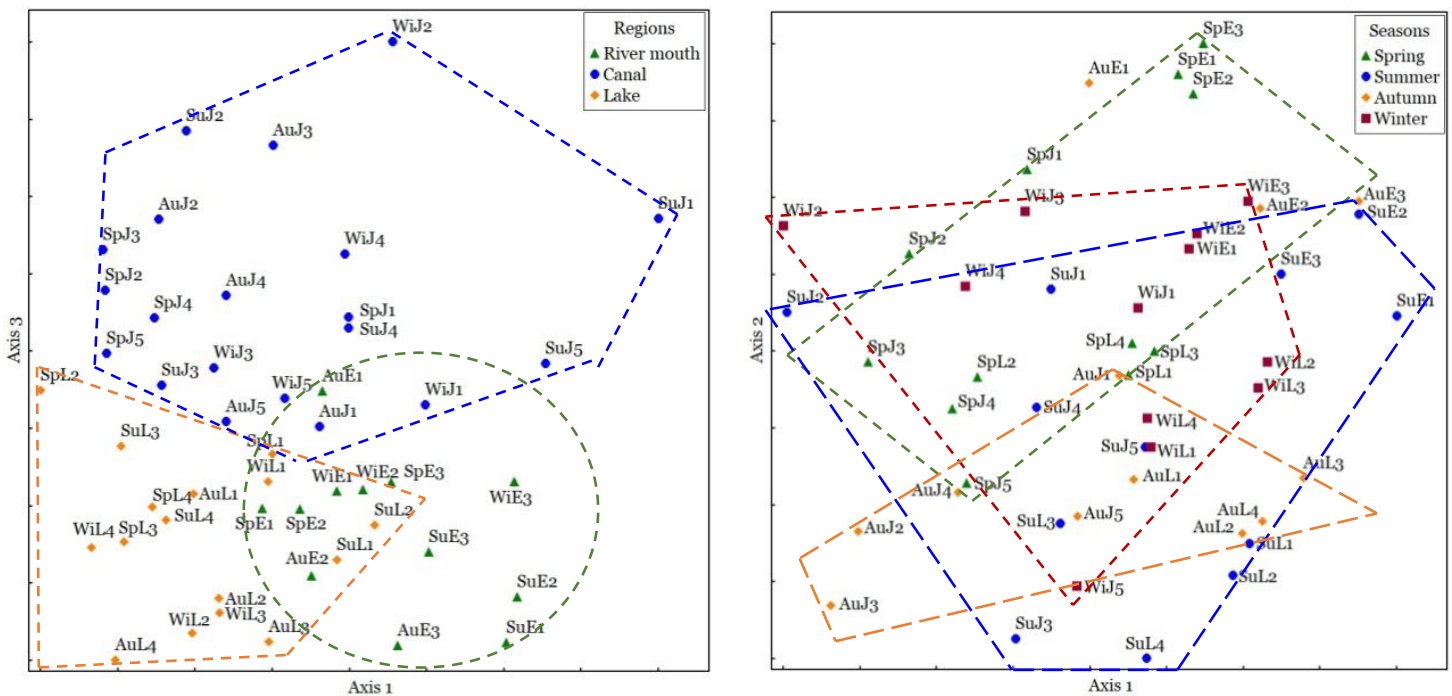

Figure 3. Non-metric multidimensional scaling (NMDS) ordination of macroinvertebrates samples over 4 seasons and 3 regions. 
Table 4. PERMANOVA analysis of macroinvertebrate communities in the Weishan Lake.

\begin{tabular}{cccccc}
\hline Source & $d f$ & SS & MS & Pseudo-F & $p$ (perm) \\
\hline Region & 2 & 27,346 & 13673 & 11.065 & 0.0001 \\
Season & 3 & 12,860 & 4286.7 & 3.4692 & 0.0001 \\
Region $\times$ Season & 6 & 15,762 & 2627 & 2.126 & 0.0001 \\
Residual & 36 & 44,484 & 1235.7 & & \\
Total & 47 & 100,540 & & & \\
\hline
\end{tabular}

$d f$ : degree of freedom, SS: square sum, MS: mean sum, $F$ : Fisher's univariate $F$ statistic, $p$ (perm): $p$ value using permutation of residuals under a reduced model.

Indicator species analysis (Table A4) evidenced that the River Mouth region was mainly classified by Culicoides sp., Orthocaldius obumbratus, Propsilocerus akamusi, Parachironomus chaetoalus, Gillotia alboviridis, Procladius sp.A, Limnodrilus grandisetosus (total of 7 indicator species) $(p<0.05)$; Canal region by Corbicula fluminea, Semisulcospira cancellata, Laonome sp., Hemiclepsis sp., Gammarus sp. and Bellamya purificata (total 6) ( $p<0.05)$; and Lake region by Einfeldia dissidens, Tanypus concavus, Cryptotendipes sp. A, Glyptotendipes amplus (total 4$)(p<0.05)$. While on the temporal scale, only six indicator species were separated out. And among them, only one indicator species (Parachironomus chaetoalus) in the spring; three (Cryptochironomus rostratus, Chironomus riparius, Microchironomus tener) in the summer; two (Propsilocerus akamusi, Dicrotendipes tritomus) in the winter, and none in autumn. Based on the indicator species, two-way cluster analysis was used to represent the above results (Figure 4), and the results illustrated how the taxa interacted through spatiotemporal scales and reveal patterns in the changing composition of the macroinvertebrates; moreover, we also found that more taxa as indicator species were screened out among the regions.
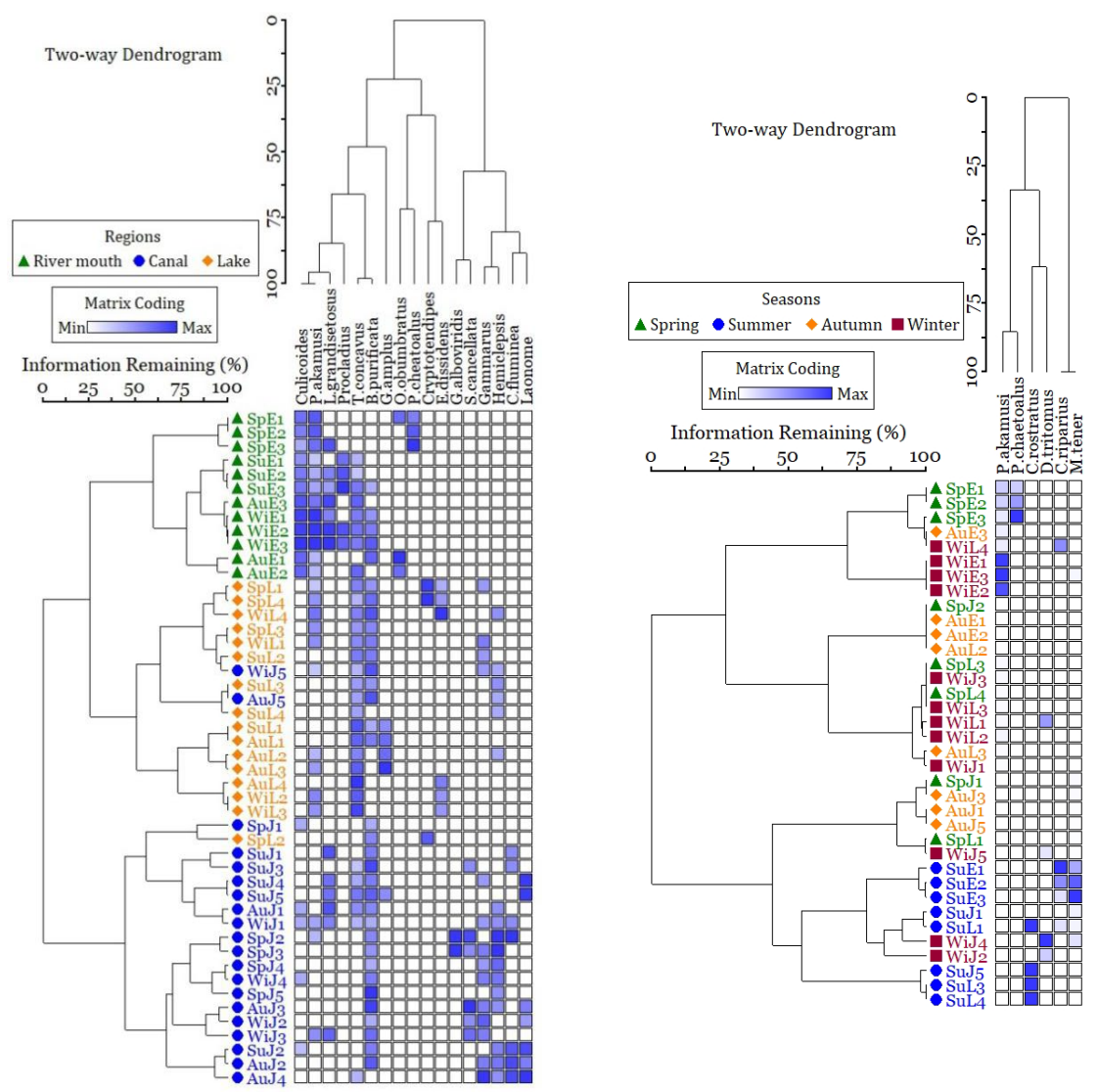

Figure 4. Two-way cluster analysis based on the indicator species among regions and seasons (samples without indicator species were rejected in the analysis). 


\subsection{Assemblage-Environmental Relationships}

The relatively important environmental variables were retained as predictors of macroinvertebrate assemblages over the study period, and among the three regions and four seasons (Figure 5 and Table 5). A total of eight environmental variables which had significant impact on the communities among seasons were confirmed; and their compositions were obviously different among seasons. Among them, $\mathrm{pH}$ was the most constant variable discriminating variance in the communities data across the studied area. However, WD significantly impacted on the communities only in spring and summer; ST, TDS in spring and winter; $\mathrm{PO}_{4}-\mathrm{P}$ in autumn and winter; $\mathrm{SD}$ and $\mathrm{NH}_{4}-\mathrm{N}$ in summer, and TP and Cond in autumn.
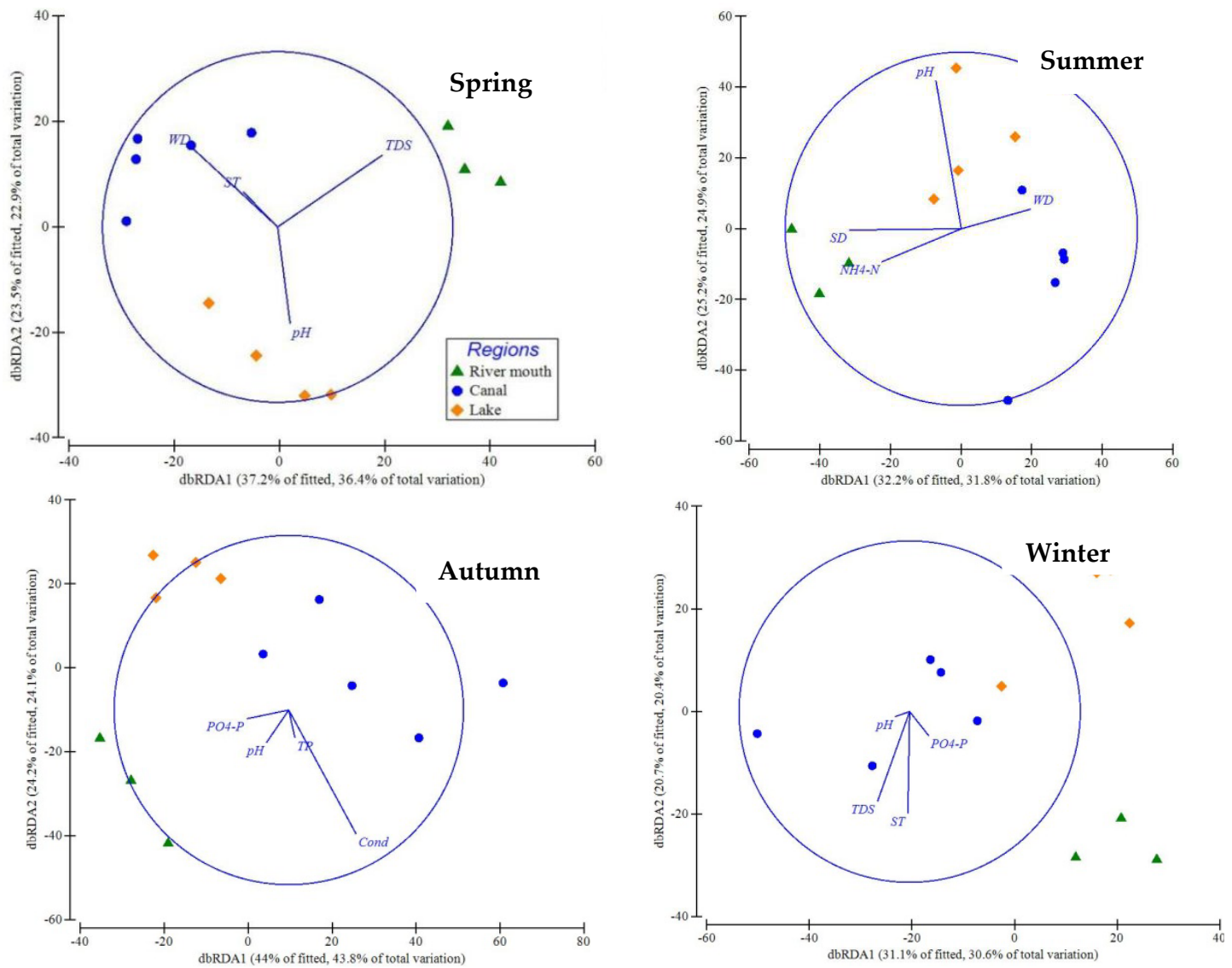

Figure 5. Ordination of distanced-based redundancy analysis (db-RDA) of macroinvertebrate assemblages to environmental parameters among seasons.

Table 5. Results of distance-based redundancy analysis (db-RDA), giving the relative influence of significant environmental variables on community composition in the four seasons.

\begin{tabular}{cccccccccc}
\hline Seasons & Variable & Adj. $\mathbf{R}^{\mathbf{2}}$ & Pseudo-F & $\boldsymbol{p}$ & Seasons & Variable & Adj. $\mathbf{R}^{\mathbf{2}}$ & Pseudo-F & $\boldsymbol{p}$ \\
\hline \multirow{2}{*}{ Spring } & $\mathrm{ST}$ & 0.27 & 5.10 & 0.001 & Autumn & $\mathrm{PO}_{4}-\mathrm{P}$ & 0.30 & 5.76 & 0.001 \\
& $\mathrm{pH}$ & 0.45 & 4.28 & 0.002 & & $\mathrm{Cond}$ & 0.52 & 5.63 & 0.001 \\
& $\mathrm{TDS}$ & 0.51 & 2.04 & 0.043 & & $\mathrm{TP}$ & 0.60 & 2.77 & 0.014 \\
& $\mathrm{WD}$ & 0.54 & 1.57 & 0.073 & & $\mathrm{pH}$ & 0.68 & 2.48 & 0.049 \\
\multirow{5}{*}{ Summer } & $\mathrm{NH}_{4}-\mathrm{N}$ & 0.22 & 4.17 & 0.001 & Winter & $\mathrm{PO}_{4}-\mathrm{P}$ & 0.16 & 3.13 & 0.002 \\
& $\mathrm{pH}$ & 0.35 & 2.97 & 0.004 & & $\mathrm{ST}$ & 0.30 & 3.01 & 0.004 \\
& $\mathrm{SD}$ & 0.44 & 2.52 & 0.010 & & $\mathrm{TDS}$ & 0.40 & 2.42 & 0.026 \\
& $\mathrm{WD}$ & 0.51 & 2.08 & 0.066 & & $\mathrm{pH}$ & 0.52 & 2.30 & 0.039 \\
\hline
\end{tabular}




\section{Discussion}

\subsection{Variation of Macroinvertebrate Assemblages}

Our study demonstrated that the differences in assemblage composition were significant among three typical habitats and four seasons in the Weishan Lake, a typical water transfer and storage shallow lake on the route of SNWD in the eastern China. To some extent, it reflected the spatial and temporal heterogeneity of habitat. The organization of macroinvertebrate assemblages are mainly related to habitat conditions and life-history traits at different spatial and temporal scales [44]. During the investigation period, the communities were mainly characterized by organic-pollution tolerant Chironomidae (e.g., Proposiloceus akamusi) and Oligochaeta (e.g., Limnodrilus hoffmeisteri) species, which occur and survive in highly degraded environments [23]. Such findings are in accordance with many studies in East Asian eutrophic lakes [23,45]. The dominance of these tolerant species indicated the Weishan Lake was in eutrophic state [46]. Comparing with the previous studies from 1960s to 2010s in this lake region (Table 6), we found dominant taxa shifted from larger mollusks (e.g., Bellamya quadrata, Alocinma longicorris) to smaller chironomids and tubificids. Such community changes were possibly related to the degradation of the water environment caused by anthropogenic disturbances. Since the 1980s, with the economic growth and nutrient input, fishing and breeding were gradually strengthened, and the water quality was gradually deteriorating, which led to the increase of small and pollution-tolerant species, such as Chironomidae and Oligochaeta [6].

Table 6. Characteristics of macroinvertebrate communities in the Nansi Lake during different periods.

\begin{tabular}{|c|c|c|}
\hline Investigation Time & Species Composition & Dominant Taxa \\
\hline 1959 & $\begin{array}{l}\text { Total } 25 \text { species. Annelida 2, } \\
\text { Mollusca 17, Arthropoda } 6 \text { species }\end{array}$ & $\begin{array}{l}\text { Dominant species were } \\
\text { Bellamya quadrata, } \\
\text { Limnoperna lacustris, } \\
\text { Lymnaeidae spp., Unio douglasiae, } \\
\text { Unio douglasiae, } \\
\text { Semisulcospira cancellata, } \\
\text { Corbicula fluminea }\end{array}$ \\
\hline 1983-1984 & $\begin{array}{l}\text { Total } 68 \text { species. Annelida } 8 \text {, } \\
\text { Mollusca36, Arthropoda } 24 \\
\text { species (Insecta } 15 \text { families) }\end{array}$ & $\begin{array}{l}\text { Dominant Mollusca species were } \\
\text { Alocinma longicorris, } \\
\text { Parafossarula siratulus, } \\
\text { Bellamya lapidea, } \\
\text { Corbicula fluminea; dominant } \\
\text { Chironomidae were } \\
\text { Chironomus plumosus and } \\
\text { Chironomus attenuatus }\end{array}$ \\
\hline 2010 & $\begin{array}{l}\text { Total } 37 \text { species. Annelida 10, } \\
\text { Mollusca 10, Arthropoda 16, } \\
\text { Nomatoda 1species }\end{array}$ & $\begin{array}{l}\text { Dominant species were } \\
\text { Limnodrilus hoffmeisteri, } \\
\text { Propsilocerus akamusi }\end{array}$ \\
\hline 2012 & $\begin{array}{l}\text { Total } 72 \text { species. Annelida 14, } \\
\text { Mollusca15, Arthropoda } 43 \text { species }\end{array}$ & $\begin{array}{l}\text { Dominant species were } \\
\text { Limnodrilus hoffmeisteri, } \\
\text { Propsilocerus akamusi, } \\
\text { Tanypus concavus, Culicoides sp. }\end{array}$ \\
\hline
\end{tabular}

Significant regional differences were observed for the abundance of main invertebrate groups and most biodiversity indices. The River Mouth regions were mainly associated with a large surface area of watersheds, large floodplains, slow water flows, and wide and deep rivers. These conditions promote a high nutrient and sediment load from the upstream parts [47,48], which provide requirements for the over population of tolerant taxa. For instance, several representative species of highly eutrophic and polluted habitats, such as Limnodrilus hoffmeisteri, Propsilocerus akamusi and Microchironomus tener [45], peaked in sites in the River Mouth region. We found that biodiversity indices (species richness, 
Margalef and Shannon-Weiner indices) were lowest in the Lake region. This was mainly because of lentic environment which led to lower habitat heterogeneity than lotic habitats; on the other hand, macrophytes (e.g., Potamogeton crispus) which produced excessive organic matter usually resulted in anaerobic sediment environment and nutrients releasing [49,50], which adversely affected the aquatic environment and the survival of macroinvertebrates [51]. In contrast, the Canal region supported the highest levels of biodiversity and mollusks abundance. The flowing environments enhanced the habitat heterogeneity, benefiting the survival of more species, e.g., filters (Gammarus sp. and bivalves), rheophilous and high-oxygen demand taxa, and thus resulted in the high biodiversity.

Many macroinvertebrate specimens usually adapt life history strategies and behaviors to meet seasonal changes in environmental conditions. In the present study, the significant assemblage differences among seasons also reflected the different life history strategies of dominant macroinvertebrate taxa [52]. For example, the abundance of Propsilocerus akamusi was much higher in spring and winter than summer and autumn (136 639 ind. $/ \mathrm{m}^{2}$ versus $5 \sim 25$ ind. $\left./ \mathrm{m}^{2}\right)$. As P. akamusi is a cold water species, it can usually migrate vertically to a depth of 20 to $40 \mathrm{~cm}$ when the bottom temperature is above $19{ }^{\circ} \mathrm{C}$ [53]. This behavior resulted in the low density of captured P. akamusi in two warm seasons, because the dredging depth of the modified Petersen grab is no more than $15 \mathrm{~cm}$. In the meantime, high temperature and low dissolved oxygen in the summer are harmful to the survival of Chironomus plumosus, though it is the indicator species of eutrophication [46]. Furthermore, spring was usually an important emergence period for most chironomids (e.g., Tanypus sp.) [54,55]. For these reasons, we observed most significant seasonal changes in chironomids abundance and composition. On the contrary, due to the relatively long life cycle of Oligochaete and Mollusca, non-seasonal changes were observed for their abundance and composition.

The dissimilarity of macroinvertebrate communities was more clear and consistent among 3 research regions than 4 seasons (mainly showed spring samples were significantly different to others in the Canal and Lake regions). Possible explanations are as followings: (1) seasonal variations of environmental factors are periodic and predictable in evolutionary time, and therefore adaptive responses to such disturbances are possible in benthic taxa [22,56]; (2) non-seasonal taxa, e.g., L. hoffmeisteri and Gammarus sp., presented in relatively high abundances throughout the entire year due to their physiological adaptability, thereby removing a potential source of temporal variation $[52,57]$.

\subsection{Relationship between Assemblages and Environmental Variables}

The dbRDA models revealed the relationship between macroinvertebrate assembles and environmental factors, and the results turned out that the influence degree of the different environmental parameters varied with seasons and regions. $\mathrm{pH}$ is an important trigger for resting-egg hatching [56], pioneer dispersers establishing [58] and so on in the aquatic environment. It is usually affected by temperature changes associated with climate, water depth, vegetation coverage, etc. [59]; this was the reason why $\mathrm{pH}$ values were higher in spring and summer, and affected macroinvertebrate communities during all the periods. High nutrient (e.g., ammonia, nitrate, orthophosphate) concentrations in the study area were mainly derived from aquaculture, agricultural and domestic sewage in the basin. Nitrogen compounds were reported toxic to aquatic organism [60], though their sensitivities usually differ among taxa [61]. Ammonia was reported as toxicant with deleterious effects on behaviors and survival of invertebrates [23]. High nutrient concentrations and eutrophic levels, as well as the reductions in habitat heterogeneity, were fatal for spatio-temporal distribution of macroinvertebrates. It is noteworthy that the environmental factors usually interact with each other, and thus make the relationships between biotic and abiotic components more complex. However, some community variations in models were still unexplained. One possibility was that low investigation frequency may let slip some key stages of macroinvertebrates life histories; secondly, other factors related to macroinvertebrate assemblages may also influence the spatio-temporal variances, such as biota interaction, substrate composition [62], macrophyte species composition and abundance [24,63], hydraulic and hydrological parameters [25], and human activities [21,64]. Furthermore, short time 
scale in situ measurements usually hardly capture the spatio-temporal distribution of emergent phenomena such as insect emergence and hatching [65].

\subsection{Implications for Aquatic Ecosystem Assessment and Management under Impact of SNWD}

Spatiotemporal processes, which can strongly affect the benthic communities, may bias the assessments of ecological status based on biological metrics [66], because temporal and spatial factors are usually not considered in most bio-assessment methods and pollution level classification. The present study improved our understanding of factors that are important for determining the structure of water ecosystems, and should result in better management practices of fresh waters that are more cost-effective and scientifically sound.

Ecological concerns surrounding IBWT projects have been virtually ignored world-wide or usually considered only as mitigation measures when problems arise [67]. Pre-transfer ecological work has rarely been undertaken [67]. Our study showed a clear pattern of water quality and macroinvertebrate communities, and identified key factors affecting macroinvertebrate community structure prior to the project operation. This was very important for subsequent assessment and management, because it provided background values for comparison with subsequent studies and improved our understanding of potential ecological impacts of large-scale hydraulic projects. For instance, the comparison of preand post-water depth (about $0.5 \mathrm{~m}$ will be increased with the operation of SNWD) is very important for understanding some ecological processes and mechanisms of water receiving lakes, e.g., nutrients release [68], eutrophication reversal and macroinvertebrate structure [69].

The implementation of SNWD may drastically change the ecological and environmental states of the related waters $[70,71]$. In general, such impacts include direct and indirect, short-term and long-term, evoked and accumulated, one-time and multiple [72]. The pre-transfer information in our study is crucial for subsequent local biodiversity conservation, sustainable fisheries and overall aquatic ecosystem health and management.

Based on our results and literature, we propose several management strategies for the SNWD. (1) Target and detailed data (biotic and abiotic) should be collected on a timely basis to support subsequent ecological assessment and management. (2) Government should prevent water pollution and adopt effective measures to protect the water environment in order to give better play to the long-term benefits of project. (3) The environmental assessments and other aspects of IBWT planning, such as the technical and economic studies, should be coordinated. (4) An overall consideration of different basins to achieve a greater range of water resources planning, scheduling, and allocation; it may optimally transfer and save water resources to reduce the loss of water [73]. (5) With changes in the hydrological system, some aquatic organisms may migrate habitats and even form invasions, affecting new aquatic ecosystems. Hence, such species should be given special attention when the project is operational.

\section{Conclusions}

In conclusion, the environmental conditions and macroinvertebrate assemblages were clearly separated at spatial and temporal scales. The River Mouth region harbored the highest abundance of chironomids, whereas the Canal region had the highest abundance of oligochaetes. Taxa richness, Margalef and Shannon-Weiner diversity indices were lowest in the sites at the Lake region. At the temporal scale, the total density and species richness were higher in winter than the other three seasons. Our study quantified the relationships between macroinvertebtate communities and environmental parameters in the Weishan Lake on the eastern route of SNWD. Although some community variations were still unexplained, we highlighted that environment changes can be well indicated by macroinvertebrate community variations and this work is one of the few reports about macroinvertebrates before the project operation. In addition, several management strategies were proposed for governments and other decision-makers to better address the adverse effects of inter basin water diversion. 
Author Contributions: Data curation, H.S.; Formal analysis, J.C., W.J.; Investigation, W.J., J.C., X.J., H.S. and T.Z.; Methodology, B.P.; Project administration, B.P.; Software, T.Z.; Writing-original draft, W.J.; Writing-review \& editing, X.J. All authors have read and agreed to the published version of the manuscript.

Funding: This research was funded by the CRSRI Open Research Program (No. CKWV2018492/KY); the National Nature Science Foundation of China (No. 51979241, 51622901, 31770460); Shandong Provincial University Youth Innovation and Technology Program, China (2019KJE020, 2020KJE008) and Open Foundation of Hebei Key Laboratory of Wetland Ecology and Conservation (hklk201906). The funders had no role in study design, data collection and analysis, decision to publish, and preparation of the manuscript.

Acknowledgments: Thanks to all authors for their efforts in conducting this research.

Conflicts of Interest: The authors declare no conflict of interest.

\section{Appendix A}

Table A1. The detail of Kruskal-Wallis tests were conducted to detect differences of parameters among seasons and regions.

\begin{tabular}{|c|c|c|c|c|c|c|c|}
\hline Factors & Spring & Summer & Autumn & Winter & River Mouth & Canal & Lake \\
\hline $\mathrm{WD}(\mathrm{cm})$ & $218 \pm 111^{\mathrm{a}}$ & $104 \pm 68^{b}$ & $196 \pm 31^{\mathrm{a}}$ & $205 \pm 29^{a}$ & $163 \pm 53^{\mathrm{a}}$ & $210 \pm 100^{\mathrm{a}}$ & $159 \pm 61^{\mathrm{a}}$ \\
\hline WT $\left({ }^{\circ} \mathrm{C}\right)$ & $15.8 \pm 2.2^{\mathrm{a}}$ & $29.1 \pm 1.2^{b}$ & $18.6 \pm 0.2^{c}$ & $6.5 \pm 0.9 \mathrm{~d}$ & $19.0 \pm 8.5^{\mathrm{a}}$ & $17.0 \pm 8.4^{\mathrm{a}}$ & $17.0 \pm 8.3^{\mathrm{a}}$ \\
\hline $\mathrm{ST}\left({ }^{\circ} \mathrm{C}\right)$ & $13.0 \pm 0.5^{\mathrm{a}}$ & $28.4 \pm 0.8^{b}$ & $17.7 \pm 0.3^{c}$ & $6.6 \pm 0.9 \mathrm{~d}$ & $16.9 \pm 8.2^{\mathrm{a}}$ & $16.5 \pm 8.2^{\mathrm{a}}$ & $15.9 \pm 8.3^{a}$ \\
\hline $\mathrm{SD}(\mathrm{cm})$ & $82.1 \pm 50.9^{\mathrm{a}}$ & $29.4 \pm 9.5^{b}$ & $46.5 \pm 11.5^{b c}$ & $62.9 \pm 6.4 \mathrm{ac}$ & $71.1 \pm 36.7^{\mathrm{a}}$ & $39.1 \pm 12.2^{b}$ & $63.6 \pm 38.9^{a}$ \\
\hline Chl-a (mg/L) & $0.10 \pm 0.06^{\mathrm{a}}$ & $0.12 \pm 0.06^{\mathrm{a}}$ & $0.09 \pm 0.05^{\mathrm{a}}$ & $0.07 \pm 0.04^{\mathrm{a}}$ & $0.04 \pm 0.01^{\mathrm{a}}$ & $0.12 \pm 0.05^{b}$ & $0.10 \pm 0.05^{b}$ \\
\hline $\mathrm{TN}(\mathrm{mg} / \mathrm{L})$ & $0.93 \pm 0.20^{\mathrm{a}}$ & $0.83 \pm 0.08^{a}$ & $1.10 \pm 0.16^{b}$ & $0.81 \pm 0.08^{\mathrm{a}}$ & $1.12 \pm 0.19^{\mathrm{a}}$ & $0.82 \pm 0.09^{b}$ & $0.90 \pm 0.13^{b}$ \\
\hline $\mathrm{NO}_{3}-\mathrm{N}(\mathrm{mg} / \mathrm{L})$ & $0.38 \pm 0.06^{\mathrm{ab}}$ & $0.37 \pm 0.06^{\mathrm{a}}$ & $0.45 \pm 0.08^{b}$ & $0.35 \pm 0.06^{\mathrm{a}}$ & $0.47 \pm 0.06^{\mathrm{a}}$ & $0.34 \pm 0.05^{b}$ & $0.39 \pm 0.04^{c}$ \\
\hline $\mathrm{NH}_{4}-\mathrm{N}(\mathrm{mg} / \mathrm{L})$ & $0.45 \pm 0.11^{a b}$ & $0.38 \pm 0.09 \mathrm{bc}$ & $0.55 \pm 0.08^{a}$ & $0.35 \pm 0.09^{c}$ & $0.57 \pm 0.09^{\mathrm{a}}$ & $0.35 \pm 0.09^{b}$ & $0.42 \pm 0.07^{b}$ \\
\hline $\mathrm{TP}(\mathrm{mg} / \mathrm{L})$ & $0.05 \pm 0.02^{a}$ & $0.04 \pm 0.01^{\mathrm{a}}$ & $0.05 \pm 0.02^{\mathrm{a}}$ & $0.04 \pm 0.01^{\mathrm{a}}$ & $0.069 \pm 0.01^{\mathrm{a}}$ & $0.033 \pm 0.01^{b}$ & $0.044 \pm 0.01^{c}$ \\
\hline $\mathrm{PO}_{4}-\mathrm{P}(\mathrm{mg} / \mathrm{L})$ & $0.032 \pm 0.01^{\mathrm{a}}$ & $0.023 \pm 0.01^{\mathrm{a}}$ & $0.027 \pm 0.01^{\mathrm{a}}$ & $0.026 \pm 0.01^{a}$ & $0.041 \pm 0.01^{\mathrm{a}}$ & $0.017 \pm 0.00^{b}$ & $0.030 \pm 0.01^{\mathrm{c}}$ \\
\hline TDS (mg/L) & $616 \pm 172^{a}$ & $580 \pm 71^{\mathrm{a}}$ & $677 \pm 132^{a}$ & $707 \pm 145^{\mathrm{a}}$ & $777 \pm 125^{\mathrm{a}}$ & $665 \pm 123^{b}$ & $521 \pm 20^{c}$ \\
\hline $\mathrm{DO}(\mathrm{mg} / \mathrm{L})$ & $9.44 \pm 0.8^{\mathrm{a}}$ & $8.42 \pm 0.7^{b}$ & $9.72 \pm 1.27^{\mathrm{a}}$ & $9.28 \pm 0.5^{a b}$ & $8.97 \pm 0.92^{\mathrm{a}}$ & $8.74 \pm 0.70^{\mathrm{a}}$ & $9.99 \pm 0.83^{b}$ \\
\hline Cond $(\mathrm{ms} / \mathrm{cm})$ & $1.16 \pm 0.21^{\mathrm{a}}$ & $1.18 \pm 0.17^{\mathrm{a}}$ & $1.04 \pm 0.20^{\mathrm{a}}$ & $1.03 \pm 0.25^{\mathrm{a}}$ & $1.23 \pm 0.15^{\mathrm{a}}$ & $1.21 \pm 0.14^{\mathrm{a}}$ & $0.88 \pm 0.15^{b}$ \\
\hline $\mathrm{pH}$ & $8.51 \pm 0.66^{\mathrm{a}}$ & $8.69 \pm 0.69^{a}$ & $7.90 \pm 0.26^{b}$ & $7.79 \pm 0.29^{b}$ & $8.02 \pm 0.33^{a}$ & $7.86 \pm 0.28^{a}$ & $8.22 \pm 0.63^{b}$ \\
\hline
\end{tabular}

Different letters indicate significant differences.

Table A2. The list of Macroinvertebrates in the Weishan Lake.

\begin{tabular}{|c|c|c|c|}
\hline Groups & Taxa & Groups & Taxa \\
\hline Arthropoda & $\begin{array}{c}\text { Culicoides sp. } \\
\text { Hydrobaenus kondio } \\
\text { Hydrobaenus pilipes } \\
\text { Orthocaldius obumbratus } \\
\text { Propsilocerus akamusi } \\
\text { Cricotopus trifasciatus } \\
\text { Cryptochironomus sp. } \\
\text { Cryptochironomus rostratus } \\
\text { Cryptotendipes sp.A } \\
\text { Cryptotendipes defectus } \\
\text { Chironomus riparius } \\
\text { Chironomus ochreatus } \\
\text { Chironomus flaviplumus } \\
\text { Chironomus acerbiphilus } \\
\text { Chironomus decorus } \\
\text { Chironomus plumosus } \\
\text { Microchironomus tener } \\
\text { Parachironomus chaetoalus } \\
\text { Parachironomus arcuatus } \\
\text { Einfeldia dissidens } \\
\text { Dicrotendipes lobifer } \\
\text { Dicrotendipes tritomus } \\
\text { Glyptotendipes barbipes } \\
\text { Glyptotendipes paripes } \\
\text { Glyptotendipes amplus } \\
\text { Gillotia alboviridis } \\
\text { Polypedilum sp. } \\
\text { Polypedilum halterale } \\
\text { Parochlus sp. } \\
\text { Rheopelopia paramaculipennis } \\
\text { Tanypus concavus } \\
\text { Procladius sp.A } \\
\text { Clinotanypus sp.A } \\
\text { Chironomidae pupa } \\
\text { Caenis sp. } \\
\text { Cheumatopsyche sp. }\end{array}$ & Mollusca & $\begin{array}{c}\text { Goera sp. } \\
\text { Coleoptera spp. } \\
\text { Ophiogomphus spinicornis } \\
\text { Macrobrachium } \\
\text { Gammarus sp. } \\
\text { Lebertia sp. } \\
\text { Alocinma longicornis } \\
\text { Cipangopaludina cahayensis } \\
\text { Parafossarulus eximius } \\
\text { Stenothyra glabra } \\
\text { Bellamya purificata } \\
\text { Bellamya aeruginosa } \\
\text { Bellamya limnophila } \\
\text { Semisulcospira cancellata } \\
\text { Hippeutis cantori } \\
\text { Corbicula fluminea } \\
\text { Lamprotula leai } \\
\text { Anodonate woodiana } \\
\text { Unio douglasiae } \\
\text { Lanceolaria gladiola } \\
\text { Novaculina chinensis } \\
\text { Limnoperna lacustris } \\
\text { Hemiclepsis sp. } \\
\text { Stephanodrilus sp. } \\
\text { Allonais pectinata } \\
\text { Aulodrius paucichaeta } \\
\text { Aulodrilus pluriseta } \\
\text { Aulodrius limnobius } \\
\text { Aulodrius americanus } \\
\text { Branchiura sowerbyi } \\
\text { Limnodrilus hoffmeisteri } \\
\text { Limnodrilus claparedianus } \\
\text { Limnodrilus grandisetosus } \\
\text { Tubifex tubifex } \\
\text { Bothrioneurum vejdovskyanum } \\
\text { Laonome sp. }\end{array}$ \\
\hline
\end{tabular}


Table A3. Pair-wise tests of PERMANOVA analysis of macroinvertebrate communities.

\begin{tabular}{|c|c|c|c|c|}
\hline & Groups & $\mathbf{t}$ & $p($ perm $)$ & Unique Perms \\
\hline \multirow{3}{*}{ Spring } & River mouth, Canal & 2.5953 & 0.019 & 56 \\
\hline & River mouth, Lake & 2.4773 & 0.0289 & 35 \\
\hline & Canal, Lake & 1.9814 & 0.0087 & 126 \\
\hline \multirow{4}{*}{ Summer } & River mouth, Canal & 2.2534 & 0.0187 & 56 \\
\hline & River mouth, Lake & 2.3062 & 0.0258 & 35 \\
\hline & Canal, Lake & 1.5762 & 0.0176 & 126 \\
\hline & River mouth, Canal & 2.43 & 0.0175 & 56 \\
\hline \multirow[t]{2}{*}{ Autumn } & River mouth, Lake & 2.3215 & 0.0279 & 35 \\
\hline & Canal, Lake & 2.2203 & 0.0143 & 126 \\
\hline \multirow{3}{*}{ Winter } & River mouth, Canal & 1.8639 & 0.0156 & 56 \\
\hline & River mouth, Lake & 2.2427 & 0.0283 & 35 \\
\hline & Canal, Lake & 1.6193 & 0.0089 & 126 \\
\hline \multirow{6}{*}{ River mouth } & Spring, Summer & 3.6132 & 0.1014 & 10 \\
\hline & Spring, Autumn & 1.7681 & 0.0996 & 10 \\
\hline & Spring, Winter & 3.1107 & 0.1062 & 10 \\
\hline & Summer, Autumn & 2.6029 & 0.105 & 10 \\
\hline & Summer, Winter & 4.1638 & 0.1022 & 10 \\
\hline & Autumn, Winter & 1.6168 & 0.0943 & 10 \\
\hline \multirow{7}{*}{ Canal } & Spring, Summer & 1.8514 & 0.0087 & 126 \\
\hline & Spring, Autumn & 1.5248 & 0.0149 & 126 \\
\hline & Spring, Winter & 1.5846 & 0.0075 & 126 \\
\hline & Summer, Autumn & 1.2885 & 0.0896 & 126 \\
\hline & Summer, Winter & 1.194 & 0.1482 & 126 \\
\hline & Autumn, Winter & 1.2743 & 0.1006 & 126 \\
\hline & Spring, Summer & 1.6654 & 0.0291 & 35 \\
\hline \multirow{5}{*}{ Lake } & Spring, Autumn & 1.9187 & 0.0274 & 35 \\
\hline & Spring, Winter & 1.4698 & 0.0265 & 35 \\
\hline & Summer, Autumn & 1.1913 & 0.2209 & 35 \\
\hline & Summer, Winter & 1.5605 & 0.0297 & 35 \\
\hline & Autumn, Winter & 1.3257 & 0.0878 & 35 \\
\hline \multirow{3}{*}{ All the year } & River mouth, Canal & 3.6323 & 0.0001 & 9937 \\
\hline & River mouth, Lake & 3.7194 & 0.0001 & 9941 \\
\hline & Canal, Lake & 2.8747 & 0.0001 & 9935 \\
\hline \multirow{6}{*}{ All the regions } & Spring, Summer & 2.429 & 0.0001 & 9910 \\
\hline & Spring, Autumn & 2.0167 & 0.0003 & 9927 \\
\hline & Spring, Winter & 1.8519 & 0.0002 & 9925 \\
\hline & Summer, Autumn & 1.5949 & 0.0106 & 9940 \\
\hline & Summer, Winter & 1.789 & 0.0007 & 9924 \\
\hline & Autumn, Winter & 1.3542 & 0.066 & 9926 \\
\hline
\end{tabular}


Table A4. Indicator species among regions and seasons.

\begin{tabular}{|c|c|c|c|c|c|}
\hline \multirow[b]{2}{*}{ Indicator Species } & \multirow[b]{2}{*}{ Maxgrp } & \multirow[b]{2}{*}{ Observed IV } & \multicolumn{2}{|c|}{ IV from Randomized Groups } & \multirow[b]{2}{*}{$p$} \\
\hline & & & Mean & S.Dev & \\
\hline Culicoides sp. & River mouth & 98.7 & 22.7 & 7.62 & 0.0002 \\
\hline Propsilocerus akamusi & River mouth & 93.7 & 31.8 & 9.36 & 0.0002 \\
\hline Limnodrilus grandisetosus & River mouth & 43.2 & 17.6 & 5.89 & 0.0022 \\
\hline Gillotia alboviridis & River mouth & 41.7 & 10.4 & 5.21 & 0.0012 \\
\hline Procladius sp.A & River mouth & 41.7 & 10.3 & 4.91 & 0.0006 \\
\hline Orthocaldius obumbratus & River mouth & 25.0 & 8.4 & 4.48 & 0.0092 \\
\hline Parachironomus chaetoalus & River mouth & 25.5 & 8.4 & 4.54 & 0.0124 \\
\hline Hemiclepsis sp. & Canal & 58.9 & 23.3 & 7.82 & 0.001 \\
\hline Bellamya purificata & Canal & 57.4 & 33.4 & 6.07 & 0.0022 \\
\hline Gammarus sp. & Canal & 46.7 & 19.5 & 6.51 & 0.0012 \\
\hline Corbicula fluminea & Canal & 35.0 & 12.5 & 5.52 & 0.0054 \\
\hline Laonome sp. & Canal & 35.0 & 12.6 & 5.53 & 0.0052 \\
\hline Semisulcospira cancellata & Canal & 30.0 & 11.9 & 5.52 & 0.0096 \\
\hline Tanypus concavus & Lake & 68.5 & 35.1 & 8.29 & 0.0022 \\
\hline Einfeldia dissidens & Lake & 37.5 & 13.7 & 6.09 & 0.0024 \\
\hline Glyptotendipes amplus & Lake & 23.3 & 10.7 & 5.22 & 0.0274 \\
\hline Cryptotendipes sp.A & Lake & 18.7 & 8.1 & 4.47 & 0.0452 \\
\hline Parachironomus chaetoalus & Spring & 25.0 & 9.2 & 5.1 & 0.0462 \\
\hline Microchironomus tener & Summer & 44.8 & 20.4 & 8.4 & 0.0154 \\
\hline Cryptochironomus rostratus & Summer & 33.3 & 9.7 & 5.2 & 0.0114 \\
\hline Chironomus riparius & Summer & 25.5 & 10.9 & 5.7 & 0.0356 \\
\hline Propsilocerus akamusi & Winter & 66.1 & 29 & 9.3 & 0.002 \\
\hline Dicrotendipes tritomus & Winter & 33.3 & 10.4 & 5.6 & 0.0094 \\
\hline
\end{tabular}

Maxgrp: maximum group, IV: indicator value, S.Dev: Standard Deviation.

\section{References}

1. Wang, Y.; Zhang, W.; Zhao, Y.; Peng, H.; Shi, Y. Modelling water quality and quantity with the influence of inter-basin water diversion projects and cascade reservoirs in the middle-lower hanjiang river. J. Hydrol. 2016, 541, 1348-1362. [CrossRef]

2. Biswas, A.K. Integrated water resources management: A reassessment: A water forum contribution. Water Int. 2004, 29, 248-256. [CrossRef]

3. Zeng, Q.; Liu, Y.; Zhao, H.; Sun, M.; Li, X. Comparison of models for predicting the changes in phytoplankton community composition in the receiving water system of an inter-basin water transfer project. Environ. Pollut. 2017, 223, 676-684. [CrossRef] [PubMed]

4. Belinda, G.; Aldridge, D.C. Inter-basin water transfers and the expansion of aquatic invasive species. Water Res. 2018, 143, 282-291.

5. Pohlner, H. Institutional change and the political economy of water megaprojects: China's south-north water transfer. Glob. Environ. Chang. 2016, 38, 205-216. [CrossRef]

6. Dong, Z.; Yan, Y.; Duan, J.; Fu, X.; Zhou, Q.; Huang, X.; Zhao, J. Computing payment for ecosystem services in watersheds: An analysis of the Middle Route Project of South-to-North Water Diversion in China. J. Environ. Sci. 2011, 23, 2005-2012. [CrossRef]

7. Burger, J. Bioindicators: A review of their use in the environmental literature 1970-2005. Environ. Bioindic. 2006, 1, 136-144. [CrossRef]

8. Odountan, H.; Abou, Y. Structure and Composition of Macroinvertebrates during Flood Period of the Nokoue Lake, Benin. Open J. Ecol. 2016, 6, 62-73. [CrossRef]

9. Belanger, D. Utilisation de la Faune Macrobenthique Comme Bio-indicateur de la Qualité de I'environnement côtier. Master's Thesis, Université de Sherbrooke, Sherbrooke, QC, Canada, 2009.

10. Prygiel, J.; Rosso-Darmet, A.; Lafont, M.; Lesniak, C.; Durbec, A.; Ouddane, B. Use of oligochaete communities for assessment of ecotoxicological risk in fine sediment of rivers and canals of the artois-picardie water basin (france). Hydrobiologia 1999, 410, 25-37. [CrossRef]

11. Vivien, R.; Tixier, G.; Lafont, M. Use of oligochaete communities for assessing the quality of sediments in watercourses of the Geneva area (Switzerland) and Artois-Picardie basin (France): Proposition of heavy metal toxicity thresholds. Ecohydrol. Hydrobiol. 2014, 14, 142-151. [CrossRef] 
12. Gerami, M.H.; Patimar, R.; Negarestan, H.; Jafarian, H.; Mortazavi, M.S. Temporal variability in macroinvertebrates diversity patterns and their relation with environmental factors. Biodiversitas J. Biol. Divers. 2016, 17, 36-43. [CrossRef]

13. Xue, L.; Yuan, Z.; Guo, F.; Xin, G.; Wang, Y. Predicting the effect of land use and climate change on stream macroinvertebrates based on the linkage between structural equation modeling and bayesian network. Ecol. Indic. 2018, 85, 820-831.

14. Jonsson, M.; Burrows, R.M.; Lidman, J.; Fältström, E.; Laudon, H.; Sponseller, R.A. Land use influences macroinvertebrate community composition in boreal headwaters through altered stream conditions. Ambio 2017, 46, 311-323. [CrossRef] [PubMed]

15. Durance, I.; Ormerod, S.J. Climate change effects on upland stream macroinvertebrates over a 25-year period. Glob. Chang. Biol. 2010, 13, 942-957. [CrossRef]

16. Wang, J.; Jiang, X.; Li, Z.; Meng, X.; Heino, J.; Xie, Z.; Wang, X.M.; Yu, J. Changes in multiple facets of macroinvertebrate alpha diversity are linked to afforestation in a subtropical riverine natural reserve. Environ. Sci. Pollut. Res. 2018, 25, 36124-36135. [CrossRef] [PubMed]

17. Miserendino, M.L.; Archangelsky, M.; Brand, C.; Epele, L.B. Environmental changes and macroinvertebrate responses in patagonian streams (argentina) to ashfall from the chaitén volcano (may 2008). Sci. Total Environ. 2012, 424, 202-212. [CrossRef]

18. Boda, P.; Móra, A.; Várbíró, G.; Csabai, Z. Livin' on the edge: The importance of adjacent intermittent habitats in maintaining macroinvertebrate diversity of permanent freshwater marsh systems. Inland Waters 2018, 8 , 312-321. [CrossRef]

19. Marin, J.R.; Miller, J.A. Spatial variability of the surf zone fish and macroinvertebrate community within dissipative sandy beaches in Oregon, USA. Mar. Ecol. 2016, 37, 1027-1035. [CrossRef]

20. Sullivan, S.M.; Manning, D.W. Seasonally distinct taxonomic and functional shifts in macroinvertebrate communities following dam removal. Peer 2017, 5, 1-14. [CrossRef]

21. Chi, S.; Li, S.; Chen, S.; Chen, M.; Zheng, J.; Hu, J. Temporal variations in macroinvertebrate communities from the tributaries in the three gorges reservoir catchment, China. Rev. Chil. De Hist. Nat. 2017, 90, 6-13. [CrossRef]

22. Jiang, X.; Xiong, J.; Xie, Z. Longitudinal and seasonal patterns of macroinvertebrate communities in a large undammed river system in southwest china. Quat. Int. 2017, 440, 1-12. [CrossRef]

23. Zhang, Y.; Liu, X.; Wang, M.; Qin, B. Compositional differences of chromophoric dissolved organic matter derived from phytoplankton and macrophytes. Org. Geochem. 2013, 55, 26-37. [CrossRef]

24. Meng, X.; Jiang, X.; Xiong, X.; Wu, C.; Xie, Z. Mediated spatio-temporal patterns of macroinvertebrate assemblage associated with key environmental factors in the qinghai lake area, China. Limnologica 2016, 56, 14-22. [CrossRef]

25. Yang, Y.F.; Zhou, X.D.; Yi, Y.J.; Xu, M.Z.; Yang, Z.F. Influence of debris flows on macroinvertebrate diversity and assemblage structure. Ecol. Indic. 2018, 85, 781-790. [CrossRef]

26. Yang, L.; Liu, E. The human pollution evaluation of phosphorus in surface sediments of Nansihu Lake. Procedia Environ. Sci. 2011, 10, 918-921.

27. Wu, Z.; Jian, Z.; Jie, Z.; Jie, R.; Shan, C. A monitoring project planning technique of the water quality spatial distribution in Nansi Lake. Procedia Environ. Sci. 2011, 10, 2320-2328.

28. Lu, M.S.; Kong, F.S.; Zhuang, X.H. Comprehensive environmental-geological survey of the Nansi Lake drainage area, southwestern Shandong. Geol. China 2003, 30, 424-428.

29. Ma, Z.D.; Gao, H.; Yang, J.; Xi, J.C.; Li, X.M.; Ge, Q.S. Valuation of Nansihu Lake wetland ecosystem services based on multi-sources data fusion. Resour. Sci. 2014, 6, 840-847.

30. Zhuang, W.; Wang, Q.; Tang, L.; Liu, J.; Yue, W.; Liu, Y.; Zhou, F.; Chen, Q.; Wang, M. A new ecological risk assessment index for metal elements in sediments based on receptor model, speciation, and toxicity coefficient by taking the nansihu lake as an example. Ecol. Indic. 2018, 89, 725-737. [CrossRef]

31. Brinkhurst, R.O. Guide to the Freshwater Aquatic Microdrile Oligochaetes of North America; Canadian Special Publication of Fisheries and Aquatic Sciences; Department of Fisheries and Oceans: Ottawa, ON, Canada, 1986.

32. Morse, J.C.; Yang, L.; Tian, L. Aquatic Insects of China Useful for Monitoring Water Quality; Hohai University Press: Nanjing, China, 1994. 
33. Epler, J.H. Identification Manual for the Larval Chironomidae (Diptera) of North and South Carolina; EPA: Florida, FL, USA, 2001.

34. Liu, Y.; Zhang, W.; Wang, Y.; Wang, E. Economic Fauna of China (Freshwater Mollusk); Science Press: Beijing, China, 1979.

35. Wang, H.Z. Studies on Taxonomy, Distribution and Ecology of Microdrile Oligochaetes of China, with Descriptions of Two New Species from the Vicinity of the Great Wall Station of China, Antarctica; Higher Education Press: Beijing, China, 2002.

36. Wang, J.C.; Wang, X.H. Chironomidae Larvae in Northern China; Yanshi Press: Beijing, China, 2011.

37. Wei, F.S.; Kou, H.R.; Hong, S.J. Methods for the Examination of Water and Wastewater; China Environmental Science Press: Beijing, China, 1989.

38. Huang, X.F.; Chen, W.; Cai, Q.H. Standard Methods for Observation and Analysis in Chinese Ecosystem Research Networke Survey, Observation and Analysis of Lake Ecology; Standards Press of China: Beijing, China, 1999.

39. McCune, B.; Mefford, M.J. PC-ORD. Multivariate Analysis of Ecological Data; Version 5; MjM Software: Gleneden Beach, OR, USA, 2006.

40. Anderson, M.J.; Gorley, R.N.; Clarke, K.R. PERMANOVA+ for PRIMER: Guide to Software and Statistical Methods; PRIMER-E: Plymouth, UK, 2008.

41. Anderson, M.J. PERMANOVA: A FORTRAN Computer Program for Permutational Multivariate Analysis of Variance; Department of Statistics, University of Auckland: Auckland, New Zealand, 2005.

42. Legendre, P.; Anderson, M.J. Distance-based redundancy analysis: Testing multispecies responses in multifactorial ecological experiments. Ecol. Monogr. 1999, 69, 1-24. [CrossRef]

43. Bunn, S.E.; Edward, D.H.; Loneragan, N.R. Spatial and temporal variation in the macroinvertebrate fauna of streams of the northern jarrah forest, western australia: Community structure. Freshw. Biol. 2010, 16, 67-91. [CrossRef]

44. Tonkin, J.D.; Death, R.G.; Collier, K.J. Do productivity and disturbance interact to modulate macroinvertebrate diversity in streams? Hydrobiologia 2012, 701, 159-172. [CrossRef]

45. Hu, Z.; Jia, X.; Chen, X.; Zhang, Y.; Liu, Q. Spatial and seasonal pattern of macrozoobenthic assemblages and the congruence in water quality bioassessment using different taxa in artificial mingzhu lake in shanghai. Chin. J. Oceanol. Limnol. 2016, 34, 928-936. [CrossRef]

46. Hirabayashi, K.; Yoshizawa, K.; Yoshida, N.; Kazama, F. Progress of eutrophication and change of chironomid fauna in Lake Yamanakako, Japan. Limnology 2004, 5, 47-53. [CrossRef]

47. Blair, N.E.; Leithold, E.L.; Aller, R.C. From bedrock to burial: The evolution of particulate organic carbon across coupled watershed-continental margin systems. Mar. Chem. 2004, 92, 141-156. [CrossRef]

48. Sor, R.; Boets, P.; Chea, R.; Goethals, P.L.M.; Lek, S. Spatial organization of macroinvertebrate assemblages in the lower mekong basin. Limnol.-Ecol. Manag. Inland Waters 2017, 64, 20-30. [CrossRef]

49. Zhang, Y.; Cheng, L.; Tolonen, K.E.; Yin, H.; Gao, J.; Zhang, Z.; Li, K.; Cai, Y. Substrate degradation and nutrient enrichment structuring macroinvertebrate assemblages in agriculturally dominated lake chaohu basins, China. Sci. Total Environ. 2018, 627, 57-66. [CrossRef] [PubMed]

50. Pan, H.Y.; Xu, X.H.; Gao, S.X. Study on Process of Nutrition Release during the Decay of Submerged Macrophytes. Res. Environ. Sci. 2008, 21, 64-68.

51. Kim, P.J.; Lee, J.H.; Huh, I.A.; Kong, D. Development of benthic macroinvertebrates sediment index (BSI) for bioassessment of freshwater sediment. Int. J. Sediment. Res. 2019, 34, 368-378. [CrossRef]

52. Johnson, R.C.; Carreiro, M.M.; Jin, H.S.; Jack, J.D. Within-year temporal variation and life-cycle seasonality affect stream macroinvertebrate community structure and biotic metrics. Ecol. Indic. 2012, 13, 206-214. [CrossRef]

53. Yamagishi, H.; Fukuhara, H. Vertical migration of Spaniotoma akamusi larvae (Diptera: Chironomidae) through the bottom deposits of Lake Suwa. Jpn. J. Ecol. 1972, 22, 226-227.

54. Gong, Z. Studies on Ecology of Macrozoobenthos in Shallow Lakes along the Middle Reaches of the Changjiang River. Ph.D. Thesis, Institute of Hydrobiology, Chinese Academy of Sciences, Beijing, China, 2002.

55. Deng, S. Macroinvertebrate Secondary Productivity and Nutritional Basis Analysis in the Shengli River. Master's Thesis, Huazhong University of Science and Technology, Wuhan, China, 2011.

56. Brendonck, L.; Riddoch, B.J.; Van de Weghe, V.; Van Dooren, T. The maintenance of egg banks in very short-lived pools-a case study with anostracans (Branchiopoda). Arch. Hydrobiol. 1998, 52, 141-161. 
57. Stubbington, R.; Greenwood, A.M.; Wood, P.J.; Armitage, P.D.; Gunn, J.; Robertson, A.L. The response of perennial and temporary headwater stream invertebrate communities to hydrological extremes. Hydrobiologia 2009, 630, 299-312. [CrossRef]

58. Boulton, A.J.; Lake, P.S. The ecology of two intermittent streams in victoria, australia: Ii. comparisons of faunal composition between habitats, rivers and years. Freshw. Biol. 1992, 27, 99-121. [CrossRef]

59. Yekta, F.A.; Kiabi, B.; Ardalan, A.A.; Shokri, M. Temporal Variation in Rocky Intertidal Gastropods of the Qeshm Island in the Persian Gulf. J. Persian Gulf 2013, 4, 9-18.

60. Soucek, D.J.; Dickinson, A. Acute toxicity of nitrate and nitrite to sensitive freshwater insects, mollusks, and a crustacean. Arch. Environ. Contam. Toxicol. 2012, 62, 233-242. [CrossRef]

61. Camargo, J.A.; Alonso, A. Ecological and toxicological effects of inorganic nitrogen pollution in aquatic ecosystems: A global assessment. Environ. Int. 2006, 32, 831-849. [CrossRef]

62. Beermann, A.J.; Elbrecht, V.; Karnatz, S.; Ma, L.; Matthaei, C.D.; Piggott, J.J.; Leese, F. Multiple-stressor effects on stream macroinvertebrate communities: A mesocosm experiment manipulating salinity, fine sediment and flow velocity. Sci. Total Environ. 2017, 610-611, 961-971. [CrossRef]

63. Dube, T.; Denecker, L.; Vuren, J.H.J.V.; Wepener, V.; Smit, N.J.; Brendonck, L. Spatial and temporal variation of invertebrate community structure in flood-controlled tropical floodplain wetlands. J. Freshw. Ecol. 2017, 32, 1-15. [CrossRef]

64. Cai, Y.; Xu, H.; Vilmi, A.; Tolonen, K.T.; Tang, X.; Qin, B.; Gong, Z.; Heino, J. Relative roles of spatial processes, natural factors and anthropogenic stressors in structuring a lake macroinvertebrate metacommunity. Sci. Total Environ. 2017, 601-602, 1702-1711. [CrossRef] [PubMed]

65. Reyjol, Y.; Argillier, C.; Bonne, W.; Borja, A.; Buijse, A.D.; Cardoso, A.C.; Daufresne, M.; Kernan, M.; Ferreira, M.T.; Poikane, S.; et al. Assessing the ecological status in the context of the european water framework directive: Where do we go now? Sci. Total Environ. 2014, 497-498, 332-344. [CrossRef]

66. Heino, J.; Melo, A.S.; Siqueira, T.; Soininen, J.; Valanko, S.; Bini, L.M. Metacommunity organization, spatial extent and dispersal in aquatic system: Patterns, processes and prospects. Freshw. Biol. 2015, 60, 845-869. [CrossRef]

67. Snaddon, C.; Davies, B.; Wishart, M. A Global Overview of Inter-Basin Water Transfer Schemes with an Appraisal of Their Ecological, Socio-Economic and Socio-Political Implications and Recommendations for Their Management; WRC Publication: Wiltshire, UK, 1999; TT 120/00.

68. Qin, B.Q.; Zhou, J.; Elser, J.J.; Gardner, W.S.; Deng, J.M.; Brookes, J.D. Water Depth Underpins the Relative Role and Fates of Nitrogen and Phosphorus in Lakes. Environ. Sci. Technol. 2020, 54, 3191-3198. [CrossRef] [PubMed]

69. Bazzantia, M.; Mastrantuonoa, L.; Pilottob, F. Depth-related response of macroinvertebrates to the reversal of eutrophication in a Mediterranean lake: Implications for ecological assessment. Sci. Total Environ. 2017, 579, 456-465. [CrossRef]

70. Li, S. China's huge investment on water facilities: An effective adaptation to climate change, natural disasters, and food security. Nat. Hazards 2012, 61, 1473-1475. [CrossRef]

71. Guo, C.B.; Chen, Y.S.; Liu, H.; Lu, Y.; Qu, X.; Yuan, H.; Sovan, L.; Xie, S.G. Modelling fish communities in relation to water quality in the impoundedlakes of China's South-to-North Water Diversion Project. Ecol. Model. 2019, 397, 25-35. [CrossRef]

72. Zhuang, W. Eco-environmental impact of inter-basin water transfer projects: A review. Environ. Sci. Pollut. Res. 2016, 23, 12867-12879. [CrossRef] [PubMed]

73. Dou, X. China's inter-basin water management in the context of regional water shortage. Sustain. Water Resour. Manag. 2018, 4, 519-526. [CrossRef]

(C) 2020 by the authors. Licensee MDPI, Basel, Switzerland. This article is an open access article distributed under the terms and conditions of the Creative Commons Attribution (CC BY) license (http://creativecommons.org/licenses/by/4.0/). 